\title{
Agreement between dual x-ray absorptiometers using pencil beam and fan beam: indicators of bone health and whole-body plus appendicular tissue composition in adult athletes
}

\author{
Óscar Tavares ${ }^{1}$ \\ João P Duarte ${ }^{2,3}$ \\ Daniela C. Costa ${ }^{2}$ \\ Paulo Sousa-e-Silva ${ }^{2}$ \\ Diogo Martinho ${ }^{2,4}$ \\ Leonardo G. O. Lus ${ }^{2,5}$ \\ Pedro Duarte-Mendes ${ }^{6}$ \\ João Valente-dos-Santos $2,7,8$ \\ Jorge Conde 9 \\ José M. Casanova ${ }^{10}$ \\ Edilson S. Cyrino ${ }^{11}$ \\ (1) Manuel J. Coelho-e-Silva ${ }^{2}$
}

\begin{abstract}
1. Department of Medical Imaging and Radiation Therapy, School of Health and Technology, Polytechnic Institute of Coimbra, Coimbra, Portugal; 2. CIDAF - UID/DTP/04213/2016, Faculty of Sport Sciences and Physical Education, University of Coimbra, Coimbra, Portugal; 3. Portuguese Foundation for Science and Technology - SFRH/BD/101083/2014, Lisbon, Portugal; 4. Portuguese Foundation for Science and Technology - SFRH/BD/121441/2016, Lisbon, Portugal; 5. LACAPS, Federal University of Alagoas (Ufal), Arapiraca, Brasil; 6. SHERU - Sport, Health \& Exercise Research Unit - Polytechnic Institute of Castelo Branco, Portugal; 7. Faculty of Physical Education and Sport, Lusófona University of Humanities and Technologies, Lisbon, Portugal; 8. Portuguese Foundation for Science and Technology - SFRH/BPD/100470/2014, Lisbon, Portugal; 9. Instituto Politécnico de Coimbra, Coimbra, Portugal; 10. Faculty of Medicine, University of Coimbra, Coimbra, Portugal; 11. Metabolism, Nutrition and Exercise Laboratory, Physical Education and Sport Center, Londrina State University.
\end{abstract}

http://dx.doi.org/10.1590/1806-9282.64.04.330

\section{SUMMARY}

OBJECTIVE: The current study was aimed to examine intra-individual variation on indicators of bone health in addition to whole-body plus appendicular tissue measurements using two concurrent assessments based on pencil beam and fan beam dual energy X-ray absorptiometry (DXA) systems in adult athletes from several sports.

METHOD: Thirty-two male participants (27.6 \pm 10.1 years) were measured on anthropometry including multifrequency bioelectric impedance and air-displacement plethysmography. Bone mineral content (BMC), bone area, fat and lean soft tissue were derived using pencil beam (Lunar DPX-MD+) and fan beam (Lunar iDXA) absorptiometry. Bone mineral density (BMD) was obtained for the femoral neck, trochanter and triangle of ward. Finally, the right thigh was defined as a region of interest (ROI). Analyses comprised intra-class correlation (ICC), Effect size (d) from mean differences of repeated measurements, coefficient of variation (CV)

RESULTS: ICC were >0.900 for all measurements. Intra-individual differences were large for BMC ( $d=1,312 ; C V=2,7 \%)$, bone area ( $d=1,761$; $C V=2,7 \%)$, fat tissue ( $d=1,612 ; C V=11 \%)$ and all indicators of appendicular lean soft tissue $(d=1,237-1687 ; C V=2,0-4,1 \%)$. A very large difference $(d=4,014 ; C V=8.4 \%)$ was diagnosed for lean soft tissue of the ROI.

CONCLUSION: Although differences among concurrent instruments for BMC and bone area, the effect size of mean differences was negligible for BMD. Fat and lean soft tissue derived from DXA should be interpreted as reference values (not criterion) due to equipment-related variation, more apparently in the ROI values.

KEYWORDS: Absorptiometry, photon. Bone density. Body composition. Athletes.

DATE OF SUBMISSION: 31-Aug-2017

DATE OF ACCEPTANCE: 09-Sep-2017

CORRESPONDING AUTHOR: Manuel Coelho-e-Silva

Estádio Universitário de Coimbra

Pavilhão III - Coimbra - Portugal - 3040-156

E-mail:mjcesilva@hotmail.com oscar@estescoimbra.pt; joaopedromarquesduarte@gmail.com danicrava@hotmail.com; paulomrss@hotmail.com dvmartinho92@hotmail.com leonardoluz.ufal@gmail.com; pedromendes@ipcb.pt j.valente-dos-santos@hotmail.com; jconde@estescoimbra.pt jmcasanova@fmed.uc.pt; edilsoncyrino@gmail.com 


\section{INTRODUCTION}

Assessment of body composition corresponds to a branch of human biology $\mathrm{y}^{\mathbf{1}, 2}$ and traditionally, body composition models comprise two compartments, ${ }^{3}$ dividing body mass into fat and fat free mass. Technological advancements have allowed the appearance of nondestructive methods of evaluating body composition, being, in general, considered in vivo methodologies. Dual energy X-ray absorptiometry (DXA) assessment is based on a model of body composition evaluation, allowing quantification of fat tissue, lean soft tissue and bone mineral content (BMC), both for the whole body and for standardized segments (head; trunk, subdivided into ribs, pelvis and spine; upper limbs and lower limbs), and it is also possible to obtain the aforementioned components in regions of interest, termed ROI. From the clinical point of view, there is considerable interest in assessment of the proximal femoral area, often the target of prosthesis, by surgery, and additionally the lumbar spine (especially L1-L4), a segment with high informative value regarding the general state of the skeletal structure.

DXA technology has gained popularity over other technologies for its speed, low cost and reduced radiation exposure. ${ }^{4,5}$ Previously, the available technology would use iodine-125 as a source of radiation, the methodology being single-photon absorptiometry (SPA), aimed to estimate the mineral content of long bones distal portion, such as radius and ulna, being described as valid. ${ }^{6}$ The SPA technology was used to obtain one of the most popular equations to determine the percentage of fat mass from the triceps and subscapular fat folds. ${ }^{7}$ DXA technology measures the attenuation of X-rays emitted at frequencies of two different energies, with iodine-125 being replaced by gadolinium-153, which emits radiation at 44 and $100 \mathrm{KeV}$. There are currently several DXA devices and manufacturers Hologic and Lunar are the most mentioned ones. ${ }^{8-10}$ DXA has been used mainly in the determination of BMC and, consequently, bone mineral density (BMD), by combining $\mathrm{BMC}$ and bone area. In fact, this is a criticism of the method, since the BMD should consider BMC by bone volume and not so much by area, assuming that there are inter-individual variations of those observed in relation to thickness measurement. Each of the manufacturers has developed models for reduction of radiological exposure, scanning time and precision gains [either by improving detec- tors resolution or by the technology of X-ray emission tubes, highlighting procedures "pencil beam" (PB) and "fan beam" (FB)]. DXA, like the generality of the technologies, has assumptions, such as the heating of tissues during the procedures of application of the method, and values of water and carbon dioxide are lost, making it necessary to transform the BMC quantified to obtain the bone mineral itself. ${ }^{5}$ Additionally, it is assumed that fat and lean mass have attenuation constants and the exposure of said tissues to low and high voltages allows determining the proportions per unit area, assuming that the thickness in the antero-posterior plane does not affect the estimates.

Most of the studies focus on the comparisons between equipment from different manufacturers (Hologic vs. Lunar) or between equipment of the same manufacturer adopting different technologies for X-ray emission, i.e., $\mathrm{PB}$ as opposed to $\mathrm{FB}^{11}$ or even among methodologies: DXA vs. computed tomography $\operatorname{scan}^{12-14}$ or by the methodology of corporal potassium measurement. ${ }^{15}$ As a general rule, studies point to an error associated with DXA technology ranging from $1 \%$ to $3 \% .^{16,17}$ The interest of Sports Sciences for body composition is due, in large part, to the search for indices of metabolic efficiency. Recently, studies have emerged to express the oxygen uptakes per unit of fat-free body mass ${ }^{\mathbf{1 8}}$ since the fat corresponds to a nonrelevant metabolic tissue, or even considering oxygen consumption in the running pattern expressed per liter of lower limb volumetry (or even mL. $\mathrm{L}^{-1} \cdot \mathrm{kg}^{-1}$ ). The expression per appendicular mass of the lower limb is especially relevant when the movement pattern does not oblige the athlete under evaluation to support the whole body mass and this happens in the cycle ergometer to obtain maximum and average mechanical power ${ }^{19}$ or in the dynamometer isokinetic technique to evaluate the moments of maximum strength (peak torques) of the muscles responsible for knee extension and flexion actions. ${ }^{20}$ However, the search for informative and noninvasive protocols on limbs volume and body mass has justified a line of study ${ }^{21-23}$ devoted to more parsimonious methodologies in terms of costs and morosity (anthropometry) based on geometric models. ${ }^{24}$ The interest in total body composition and of particular segments has been especially emphasized for the lower limb or only for the thigh. Despite the popularity of the DXA technology, studies about com- 
peting equipment to estimate the determination accuracy of fat tissue, lean soft tissue and BMC are not abundant for the whole body and particular segments. In fact, the possible absence of agreement among equipments shall partially compromise proposals of calibration of new equations. ${ }^{21-23}$

The present study aims to examine agreement among indicators resulting from the application of competing DXA from manufacturer Lunar, namely taking into account Lunar DPX-MD+ (PB technology) and Lunar iDXA (FB technology), having been carried out with healthy young adults from multiple sports.

\section{METHODS}

\section{Procedures and sample}

The present study is cross-sectional in nature and adopts procedures recommended for human research $^{25}$ having been approved by a Research Ethics Committee (REC) (CE/FCDEF-UC/00102014). The research design comprises several models of body composition assessment and, in the case of DXA, two pieces of equipment from manufacturer Lunar (DPX$\mathrm{MD}+$ and iDXA). All measurements were carried out on the same day and by qualified technicians in duly certified laboratory units. Sample subjects were informed about the study objectives and the nature of the procedures, having signed an Informed Consent Form (ICF). The final sample corresponds to 32 moderately active adult males (27.6 \pm 10.1 years) practicing various sport modalities.

\section{Anthropometry}

Height and sitting height were measured to the nearest $0.1 \mathrm{~cm}$ (stadiometer Harpenden, model 98,603, Holtain Ltd., Crosswell, GB, and Harpenden Sitting Height Table). Lower limbs length was calculated by the difference from previous measurements. Body mass was obtained by a SECA (model 770, Hanover, MD, USA) scale with a reduction of $0.1 \mathrm{~kg}$. All measurements were performed by the same evaluator.

\section{Bioelectric impedance}

Participants adopted a standing position, following the manufacturer's instructions. After removing shoes, socks and other clothes, total body water was evaluated by a multifrequency bioelectrical impedance analyzer, 1, 5, 50, 250, 500, 1,000 kHz (InBody 770 scanner: In-body Bldg, Seul, Korea).

\section{Plethysmography of displaced air}

Information on body volume was obtained through displaced air plethysmography (BODPOD composition system, model BODPOD 2006, Life Measurement, Inc, Concord, CA, USA). Participants were evaluated twice consecutively following the manufacturer's instructions. Body density was calculated by dividing body mass (kg) by body volume (L).

\section{Dual energy $\mathrm{x}$-ray absorptiometry (DXA)}

The two DXA instruments used were: Lunar DPX-MD+ (Software: enCORE version 4,00,145, GE Lunar Corporation, 726 Heartland Trail, Madison, WI 53717-1915 USA) and Lunar iDXA (enCORE version 13,60,033, GE Medical Systems Lunar3030, Ohmeda Drive, Madison, WI 53718 USA). For each of the equipments, a full body scanner was carried out. Additionally, area near the femur [information on the BMD of the femur neck, Ward triangle, trochanter and body of the femur (or shaft)] was carried out for each equipment. Subsequently, in the processing phase, an ROI (right thigh) was defined, as described in previous studies. ${ }^{22,23}$ For the whole body and each and every segment, the information includes BMC and bone area to subsequently determine the BMD and the component of the fat tissue and lean soft tissue. Calibration was performed on the same day, before the first one, using the model ("phantom") and the procedures recommended by the manufacturer.

For the Lunar DPX-MD+ equipment, technical documentation specifies that it is a device with X-ray emission by $\mathrm{PB}$ technology, having a potential of $76 \mathrm{kV}$, with an accuracy of $<1 \%$ for BMD (whole body) and also $1 \%$ for body composition without specifying whether it applies to both tissues (fat tissue and lean soft tissue). In turn, one of the innovations announced in the iDXA technical leaflet concerns the FB issue. Although iDXA has an FB narrow-angle device and proceeds to multiple passages, the FB technology is understood as having higher error, which is due to interindividual variation of body size of those evaluated, especially in the sagittal measurements. Reduction of the FB angle and overlapping of scans, successively obtained, supposedly mitigates the error associated with FB equipment with wider angle (wide-angle $\mathrm{FB}$ ). The $\mathrm{X}$-ray in the Lunar iDXA equipment presents potential of $100 \mathrm{kV}$ (slightly higher than Lunar DPX-MD+) and, beyond the FB narrow-angle technology, iDXA 
is different from previous equipment by having a high resolution detector (CZT-HD).

\section{Statistical analysis}

Analyses comprised descriptive statistics (range, mean, standard error of the mean, confidence intervals of the mean and standard deviation) for the entire sample $(n=32)$, as well as the verification of normality assumptions. Subsequently, intra-individual differences (time 1 and time 2) have been determined, parallel to the calculation of the technical error of measurement (TEM). ${ }^{26}$ Then, and based on TEM, the coefficient of variation was determined (CV \%: expressed as a percentage of the combined mean of repeated measurements). Also based on associative statistics, it was possible to determine the intraclass correlation coefficient (ICC) and its 95\% confidence interval. The differences of the means of the repeated measurements were evaluated based on the effect size (Cohen's $d$ ), which have been qualitatively interpreted as follows: ${ }^{27}<0.2$ (trivial); 0.20.6 (small); 0.6-1.2 (moderate); 1.2-2.0 (large); 2.04.0 (very large); > 4.0 (extremely large). Statistical procedures were carried out using resources from software IBM SPSS v. 23 for Mac OS software (SPSS Inc., IBM Company, NY, USA).

\section{RESULTS}

Table 1 summarizes the characteristics of the sample. BMC, bone area used in determination of BMD, whole body lean soft tissue and whole body fat tissue, are presented in Table 2. Also the outputs related to BMD in the proximal femoral area are presented in Table 2 [femur neck, triangle of ward, trochanter and shaft]. Table 2 includes data from Lunar DPX-MD+ and Lunar iDXA. Violation of assumptions of normal distribution was uniquely noted for fat tissue with regard to the whole body.

Comparison of results by two competing pieces of equipment (Table 3) suggests a substantial intraindividual difference for whole body BMC (mean of intraindividual difference $=110 \mathrm{~g}$, magnitude of the wide effect: $d=1,312$ ) and also for the bone area used in calculating BMD (mean intraindividual difference $=65 \mathrm{~cm}^{2}$, effect: $\mathrm{d}=1.761$ ). However, for the BMD intraindividual differences were negligible $(-0,001$ g. $\left.\mathrm{cm}^{-}{ }^{2}\right)$ and the magnitude effect was trivial. In addition, magnitude of the intraindividual difference was large for the fat tissue, with the average being 11.87 $\mathrm{kg}$ for equipment Lunar DPX-MD+ and $13.56 \mathrm{~kg}$ for equipment Lunar iDXA, corresponding to a mean of intraindividual differences of $1.70 \mathrm{~kg}(\mathrm{~d}=1.612$, magnitude of the wide effect). Differences for the lean tissue were trivial, that is, $0.04 \mathrm{~kg}$.

BMD values for the proximal femoral area showed that for the femoral neck. The variation associated with the equipment corresponded to a trivial intraindividual difference of $0.001(\mathrm{~d}=0.031)$ and the magnitude of the differences among intraindividual means for the Ward triangle and trochanter was respectively, $\mathrm{d}=0.512$ (small magnitude) and $\mathrm{d}=0.495$ (small magnitude). For the shaft of the femur, the magnitude of the differences was moderate $(\mathrm{d}=0.656)$.

TABLE 1 DESCRIPTIVE STATISTICS FOR THE TOTAL SAMPLE AND TEST FOR NORMALITY ON ILLUSTRATIVE VARI$\operatorname{ABLES}(\mathrm{N}=32)$

\begin{tabular}{|c|c|c|c|c|c|c|c|c|}
\hline \multirow[t]{2}{*}{ Variable } & \multicolumn{2}{|c|}{ Range } & \multicolumn{3}{|c|}{ Mean } & \multirow{2}{*}{$\begin{array}{l}\text { Standard } \\
\text { deviation }\end{array}$} & \multicolumn{2}{|c|}{$\begin{array}{l}\text { Normality } \\
\text { (Kolmogor- } \\
\text { ov-Smirnov) }\end{array}$} \\
\hline & minimum & maximum & value & $\begin{array}{c}\text { standard } \\
\text { error }\end{array}$ & $95 \% \mathrm{Cl}$ & & value & $\mathrm{p}$ \\
\hline Chronological age (years) & 18,60 & 57,80 & 27,80 & 1,75 & $(24,19$ a 31,06$)$ & 10,08 & 0,326 & $<0,01$ \\
\hline Training experience (years) & 2,00 & 47,0 & 15,5 & 1,7 & $(12,2$ a 18,8$)$ & 9,6 & 0,185 & $<0,01$ \\
\hline Stature $(\mathrm{cm})$ & 155,7 & 193,0 & 176,0 & 1,5 & $(173,1$ a 179,0$)$ & 8,6 & 0,160 & 0,03 \\
\hline Sitting height $(\mathrm{cm})$ & 85,3 & 100,0 & 92,4 & 0,7 & $(91,1$ a 93,7$)$ & 3,9 & 0,107 & 0,20 \\
\hline Leg length $(\mathrm{cm})$ & 70,4 & 94,6 & 83,6 & 1,0 & $(81,7$ a 85,6$)$ & 5,7 & 0,091 & 0,20 \\
\hline Body mass (kg) & 58,4 & 91,6 & 73,5 & 1,6 & $(70,4$ a 76,6$)$ & 9,1 & 0,090 & 0,20 \\
\hline Whole body volume by ADP (L) & 54,414 & 88,360 & 69,060 & 1,574 & $(65,975$ a 72,145$)$ & 9,041 & 0,100 & 0,20 \\
\hline Whole body density by ADP (kg.L-1) & 1,028 & 1,096 & 1,065 & 0,003 & $(1,060$ a 1,071$)$ & 0,016 & 0,168 & 0,02 \\
\hline Total body water by $\mathrm{BIA}(\mathrm{L})$ & 38,0 & 55,0 & 45,6 & 0,9 & $(43,9$ a 47,3$)$ & 4,9 & 0,106 & 0,20 \\
\hline
\end{tabular}

ADP (air displacement plethysmography), BIA (body impedance), 95\% CI (95\% confidence intervals). 
TABLE 2 DESCRIPTIVE STATISTICS AND TEST FOR NORMALITY ON OUTPUTS DERIVED FROM EACH OF THE TWO DUAL ENERGY X-RAY ABSORPTIOMETRY EQUIPMENTS USED IN THE PRESENT STUDY $(\mathrm{N}=32)$.

\begin{tabular}{|c|c|c|c|c|c|c|c|c|c|}
\hline \multirow{2}{*}{ Equipment } & \multirow{2}{*}{ Parameter } & \multirow{2}{*}{ Units } & \multicolumn{2}{|c|}{ Range } & \multicolumn{2}{|c|}{ Média } & \multirow{2}{*}{$\begin{array}{l}\text { standard } \\
\text { deviation }\end{array}$} & \multicolumn{2}{|c|}{$\begin{array}{l}\text { Kolmogorov- } \\
\text { Smirnov }\end{array}$} \\
\hline & & & minimum & maximum & value & $\begin{array}{l}\text { standard } \\
\text { error }\end{array}$ & & value & $\mathrm{p}$ \\
\hline \multirow[t]{3}{*}{ DPX-MD+ } & $B M C$ & g & 2294 & 4303 & 3370 & 85 & 491 & 0,135 & 0,14 \\
\hline & Bine area & $\mathrm{cm}^{2}$ & 2068 & 3019 & 2583 & 40 & 227 & 0,134 & 0,14 \\
\hline & BMD & g.cm ${ }^{-2}$ & 1,000 & 1,483 & 1,293 & 0,019 & 0,109 & 0,071 & 0,20 \\
\hline \multirow[t]{3}{*}{ iDXA } & $B M C$ & g & 2368 & 4147 & 3260 & 80 & 459 & 0,145 & 0,08 \\
\hline & Bone area & $\mathrm{cm}^{2}$ & 2199 & 2854 & 2519 & 31 & 177 & 0,112 & 0,20 \\
\hline & BMD & g.cm ${ }^{-2}$ & 1,118 & 1,509 & 1,293 & 0,019 & 0,108 & 0,141 & 0,09 \\
\hline
\end{tabular}

\begin{tabular}{l|l|l|c|c|c|c|c|c|c}
\hline DPX-MD+ & Lean soft tissue & $\mathrm{kg}$ & 48,483 & 66,415 & 57,508 & 0,881 & 5,062 & 0,104 & 0,20 \\
\hline & Fat tissue & $\mathrm{kg}$ & 4,488 & 28,222 & 11,865 & 1,100 & 6,321 & 0,171 & 0,02 \\
\hline iDXA & Lean soft tissue & $\mathrm{kg}$ & 47,391 & 66,874 & 57,466 & 0,939 & 5,395 & 0,101 & 0,20 \\
\hline & Fat tissue & $\mathrm{kg}$ & 6,749 & 27,216 & 13,564 & 0,960 & 5,516 & 0,17 & 0,02 \\
\hline
\end{tabular}

\begin{tabular}{|c|c|c|c|c|c|c|c|c|c|}
\hline DPX-MD+ & Femural neck & g.cm-2 & 0,847 & 1,615 & 1,218 & 0,032 & 0,186 & 0,092 & 0,20 \\
\hline & Traingle of Ward & g.cm-2 & 0,636 & 1,734 & 1,145 & 0,038 & 0,220 & 0,081 & 0,20 \\
\hline & Trochanter & g.cm-2 & 0,807 & 1,322 & 1,057 & 0,036 & 0,147 & 0,094 & 0,20 \\
\hline & Shaft & g. $\mathrm{cm}^{-2}$ & 1,119 & 2,073 & 1,469 & 2,073 & 0,220 & 0,220 & 0,09 \\
\hline \multirow[t]{4}{*}{ iDXA } & Femural neck & g.cm-2 & 0,843 & 1,624 & 1,219 & 0,031 & 0,175 & 0,114 & 0,20 \\
\hline & Traingle of Ward & g.cm $\mathrm{cm}^{-2}$ & 0,613 & 1,704 & 1,125 & 0,039 & 0,225 & 0,079 & 0,20 \\
\hline & Femural neck & g. $\mathrm{cm}^{-2}$ & 0,802 & 1,331 & 1,041 & 0,027 & 0,155 & 0,104 & 0,20 \\
\hline & Shaft & g. $\mathrm{cm}^{-2}$ & 1,110 & 2,069 & 1,444 & 0,037 & 0,215 & 0,141 & 0,09 \\
\hline
\end{tabular}

\begin{tabular}{l|l|l|c|c|c|c|c|c|c}
\hline DPX-MD+ & LST: trunk & $\mathrm{kg}$ & 21,923 & 31,503 & 26,101 & 0,472 & 2,709 & 0,109 & 0,20 \\
\hline & LST: upper limbs & $\mathrm{kg}$ & 5,094 & 8,536 & 6,986 & 0,169 & 0,974 & 0,092 & 0,20 \\
\hline & LST: lower limbs & $\mathrm{kg}$ & 16,526 & 23,875 & 20,406 & 0,346 & 1,985 & 0,113 & 0,20 \\
\hline & LST: right thigh & $\mathrm{kg}$ & 3,370 & 6,348 & 4,976 & 0,117 & 0,672 & 0,142 & 0,09 \\
\hline \multirow{2}{*}{ iDXA } & LST: trunk & $\mathrm{kg}$ & 22,567 & 31,302 & 26,883 & 0,441 & 2,533 & 0,118 & 0,20 \\
\hline & LST: upper limbs & $\mathrm{kg}$ & 5,164 & 8,940 & 7,211 & 0,181 & 1,038 & 0,109 & 0,20 \\
\hline & LST: lower limbs & $\mathrm{kg}$ & 15,809 & 23,719 & 19,886 & 0,377 & 2,164 & 0,126 & 0,20 \\
\hline & LST: right thigh & $\mathrm{kg}$ & 4,321 & 7,203 & 5,494 & 0,125 & 0,717 & 0,112 & 0,20 \\
\hline
\end{tabular}

LEGENDS: bone mineral content (BMC), bine mineral density (BMD), LST (lean soft tissue)

For lean soft tissue indicators, differences were observed for all segments and ROI: $\mathrm{d}=1.687$ (large differences) for the trunk; $\mathrm{d}=1.237$ (large effect size) for upper limbs; $d=1.402$ (also large effect) for the lower limbs. For the ROI, the lean soft tissue showed a vary large variation between equipments $(\mathrm{d}=4.014)$.

With regard to the ICCs, for all measures above, ICC $>0.900$ was obtained. The CV \% fluctuated between $2.3 \%$ and $2.7 \%$ for the measures used in cal- culation of BMD. For tissue, CV \% is only $1.5 \%$ for the lean soft tissue component and $11.2 \%$ for the fat tissue component. For the variables of the proximal femoral area, TEM was always less than $5 \%$ of the combined mean [i.e., CV \% equal to $2.4 \%$ for the femoral neck, 2.5\% for the Ward triangle, 2.0\% for the trochanter and $4.5 \%$ for the shaft], the data quality being corroborated by ICC coefficients always higher than 0.950. For lean soft tissue, CV \% $=2.1$ 
TABLE 3 COMPARISONS BETWEEN EQUIMENTS (DPXMD+ MINUS IDXA)

\begin{tabular}{|c|c|c|c|c|c|c|c|c|c|c|c|}
\hline \multirow{2}{*}{$\begin{array}{l}\text { Dependent } \\
\text { variable }\end{array}$} & \multirow{2}{*}{ Units } & \multicolumn{2}{|c|}{$95 \% \mathrm{LC}$} & \multicolumn{2}{|c|}{$\begin{array}{l}\text { Intra-individual } \\
\text { mean differences }\end{array}$} & \multicolumn{2}{|c|}{ Effect size } & \multicolumn{2}{|c|}{ TEM } & \multicolumn{2}{|r|}{ ICC } \\
\hline & & DPX-MD+ & iDXA & value & $95 \% \mathrm{Cl}$ & d & qualitative & value & $\% \mathrm{CV}$ & value & (IC 95\%) \\
\hline BMC & g & $(3202 ; 3537)$ & $(3103 ; 3416)$ & 110 & $(86$ a 134) & 1,312 & (larga) & 91 & $2,7 \%$ & 0,995 & $(0,990$ a 0,998) \\
\hline Bone area & $\mathrm{cm}^{2}$ & $(2506 ; 2661)$ & $(2458 ; 2579)$ & 65 & (39 a 91) & 1,761 & (larga) & 69 & $2,7 \%$ & 0,966 & $(0,931$ a 0,983$)$ \\
\hline BMD & g.cm-2 & $(1,255 ; 1,330)$ & $(1,256 ; 1,330)$ & $-0,001$ & $(-0,016$ a 0,014$)$ & 0,000 & (trivial) & 0,029 & $2,2 \%$ & 0,961 & $(0,922$ a 0,981$)$ \\
\hline Lean soft tissue & $\mathrm{kg}$ & $(55,781 ; 59,235)$ & $(55,625 ; 59,307)$ & 0,04 & $(-0,395$ a 0,478$)$ & 0,043 & (trivial) & 0,85 & $1,4 \%$ & 0,986 & $(0,972$ a 0,993$)$ \\
\hline Fat tissue & $\mathrm{kg}$ & $(9,709 ; 14,022)$ & $(11,682 ; 15,446)$ & $-1,70$ & $(-2,084 a-1,314)$ & 1,612 & (larga) & 1,41 & $11,1 \%$ & 0,992 & $(0,983$ a 0,996) \\
\hline
\end{tabular}

\begin{tabular}{l|l|l|l|l|l|l|l|l|l|l|l}
\hline Femural neck & g.cm & $(1,154 ; 1,281)$ & $(1,159 ; 1,279)$ & 0,001 & $(-0,016$ a 0,014) & 0,031 & (trivial) & 0,030 & $2,4 \%$ & 0,986 & $(0,971$ a 0,933) \\
\hline Traingle of Ward & g.cm & $(1,070 ; 1,221)$ & $(1,048 ; 1,202)$ & 0,020 & $(0,008$ a 0,033) & 0,512 & (pequena) & 0,028 & $2,4 \%$ & 0,994 & $(0,988$ a 0,977) \\
\hline Trochanter & g.cm -2 & $(1,007 ; 1,107)$ & $(0,989 ; 1,094)$ & 0,015 & $(0,006$ a 0,024) & 0,495 & (pequena) & 0,021 & $1,9 \%$ & 0,993 & $(0,986$ a 0,977) \\
\hline Shaft & g.cm -2 & $(1,394 ; 1,544)$ & $(1,370 ; 1,517)$ & 0,025 & $(-0,007$ a 0,058) & 0,656 & (moderada) & 0,066 & $4,5 \%$ & 0,954 & $(0,908$ a 0,977) \\
\hline
\end{tabular}

\begin{tabular}{l|l|l|l|l|l|l|l|l|l|l|l}
\hline LST: trunk & $\mathrm{g}$ & $(25,177 ; 27,026)$ & $(26,019 ; 27,747)$ & $-0,78$ & $(-1,090$ a - 0,474$)$ & 1,687 & (larga) & 0,81 & $2,0 \%$ & 0,972 & $(0,943$ a 0,986) \\
\hline LST: upper limbs & $\mathrm{g}$ & $(6,654 ; 7,318)$ & $(6,857 ; 7,565)$ & $-0,23$ & $(-0,352$ a -0,098) & 1,237 & (larga) & 0,29 & $4,1 \%$ & 0,967 & $(0,934$ a 0,984) \\
\hline LST: lower limbs & $\mathrm{g}$ & $(19,728 ; 21,083)$ & $(19,148 ; 20,624)$ & 0,52 & $(0,254$ a 0,785) & 1,402 & (larga) & 0,63 & $3,1 \%$ & 0,966 & $(0,932$ a 0,983$)$ \\
\hline LST: right thigh & $\mathrm{g}$ & $(4,747 ; 5,205)$ & $(5,250 ; 5,739)$ & $-0,52$ & $(-0,644$ a -0,393) & 4,014 & (muito larga) & 0,44 & $8,4 \%$ & 0,931 & $(0,860$ a 0,966) \\
\hline
\end{tabular}

(Software: enCORE GE Healthcare 2011 version 13,60) and Lunar iDXA (ME+210160 Software: enCORE GE Healthcare 2012 version 15,00), intra-individual mean differences and respective $95 \%$ confidence intervals ( $n=32)$ and technical error of measurement (TEM), coefficient of variation (\%CV) and intra-class correlation coefficient (ICC).

Note: BMC: bone mineral content; BMD: bone mineral density; LST: lean soft tissue; 95\%CL: 95\% confidence limits; TEM: technical error of measurement; CV: coefficient of variation; ICC: intra-class coefficient of correlation.

and ICC $=0.972$ for the trunk, CV \% $=4.2$ and ICC $=0.967$ for the upper limbs; $\mathrm{CV} \%=3.2$ and ICC $=$ 0.966 for the lower limbs were observed. For the ROI, the lean soft tissue showed a higher variation between equipment $(\mathrm{CV} \%=8.43, \mathrm{ICC}=0.931)$.

\section{DISCUSSION}

In the present study, agreement among indicators resulting from the application of competing equipments used in DXA, one being a PB technology (Lunar DPX-MD+) and another, FB (Lunar iDXA) was examined. Regarding BMC, the bone area for determining BMD, BMD, fat tissue and lean soft tissue, healthy adults and sportsmen of various sports were assessed. Negligible differences were found for BMD, despite a trend for Lunar DPX-MD+ to produce higher values for BMC and also for the bone area. In a study of women between the ages of 21 and $80,{ }^{11}$ there was a trend for the FB mode to underestimate (by comparison to the PB mode) the bone area used to calculate BMD. This study, previously mentioned, was carried out with the equipment Hologic QDR-2000, that has the possibility of adopting the two modes mentioned above (FB and PB). ${ }^{5}$ However, other studies ${ }^{28,29}$ shoed that among FB technology equipment, the subject's thickness constitutes a source of discrepancy. The
Lunar manufacturer's first equipment had a beam angle of about 30 degrees, considering wide-angle $\mathrm{FB},{ }^{30}$ having been replaced by narrow-angle FB equipment (in the Lunar Prodigy equipment the angle is 4.5 degrees), and considered several overlapping scans, which takes place in the Lunar iDXA (equally a narrow-angle $\mathrm{FB}$, with the added advantage of being equipped with a CZT-HD high resolution detector). In the present study, a high ICC was always obtained between the aforementioned narrow-angle FB (iDXA) equipment and the PB (Lunar DPX-MD+) equipment.

For measurements of the proximal femoral area, which are widely used in clinical settings, BMD presented differences between equipment which fluctuated between trivial and moderate, although $\mathrm{CV}$ $\%$ and ICC confirmed a certain idea of data quality, especially for the femur neck, trochanter and Ward triangle, revealing shaft as a more problematic parameter. The literature confirms this trend for variation in the discrepancy between FB and PB modes, namely in a study of 63 women ${ }^{11}$ which made it possible to conclude that there was an overestimation of $+1.5 \%$ by FB in the lumbar spine, in parallel with an underestimation of $-0.7 \%$ in the femoral neck and $-1.8 \%$ in the trochanter. In the latter region, a correlation of +0.36 was found among the residuals of the two modes $(\mathrm{FB} / \mathrm{PB})$ and the body mass of the women 


\section{BONE MINEARAL DENSITY}

A.

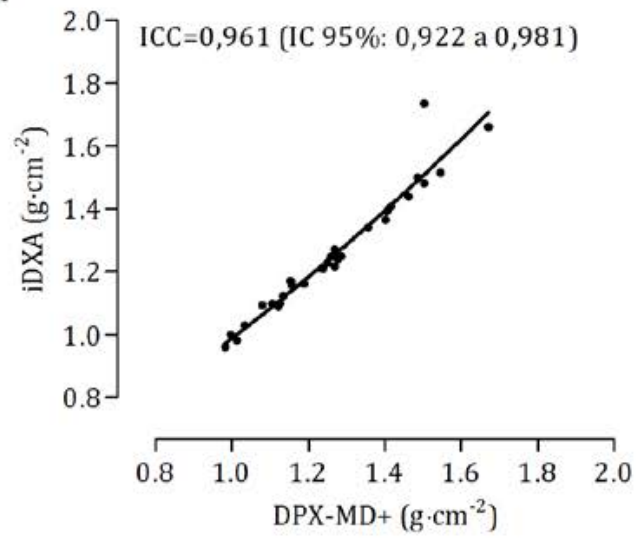

B.

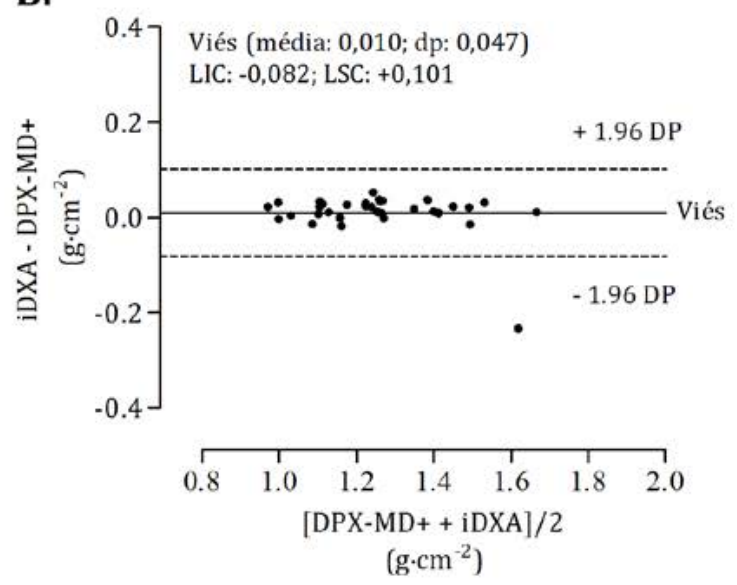

\section{LEAN SOFT TISSUE}

C.

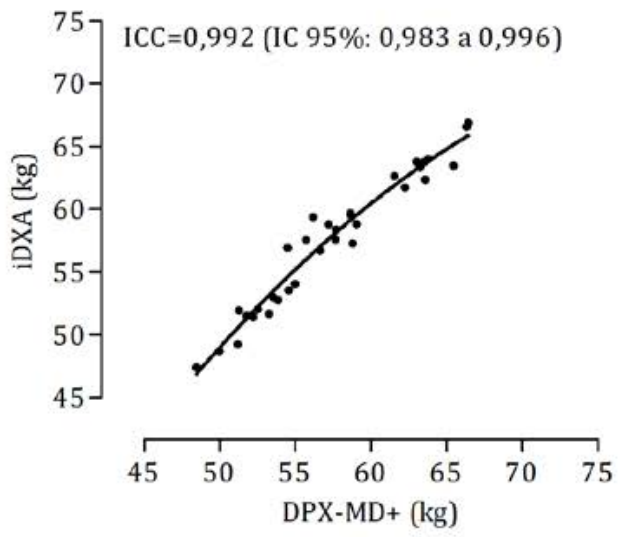

D.

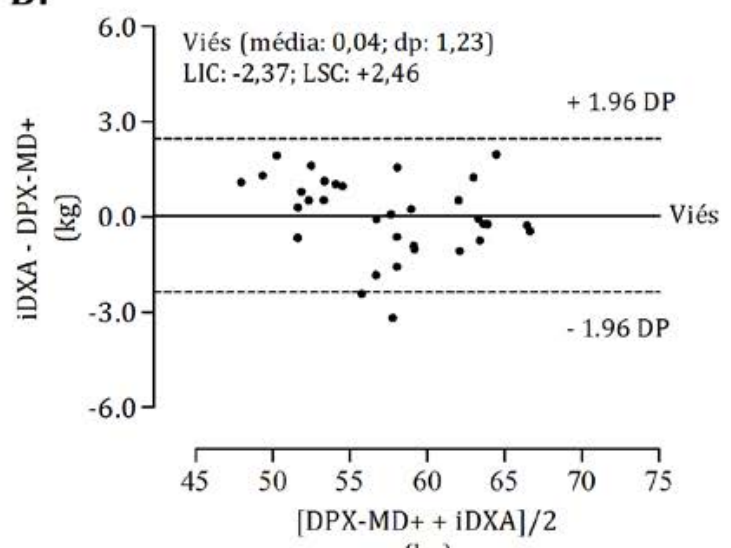

$(\mathrm{kg})$

\section{FAT TISSUE}

E.

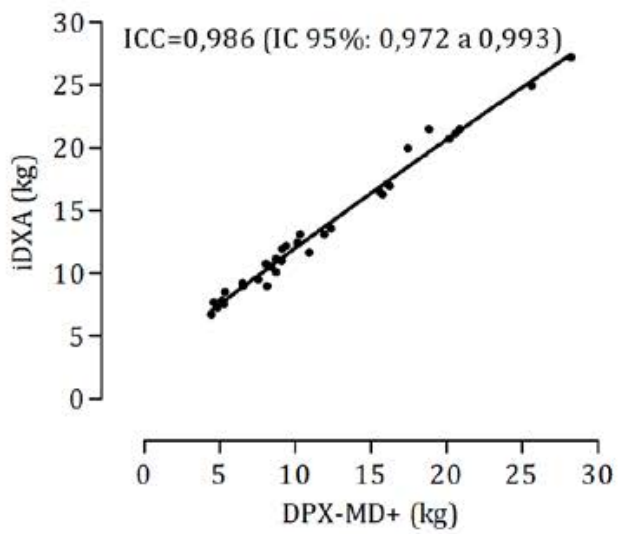

F.

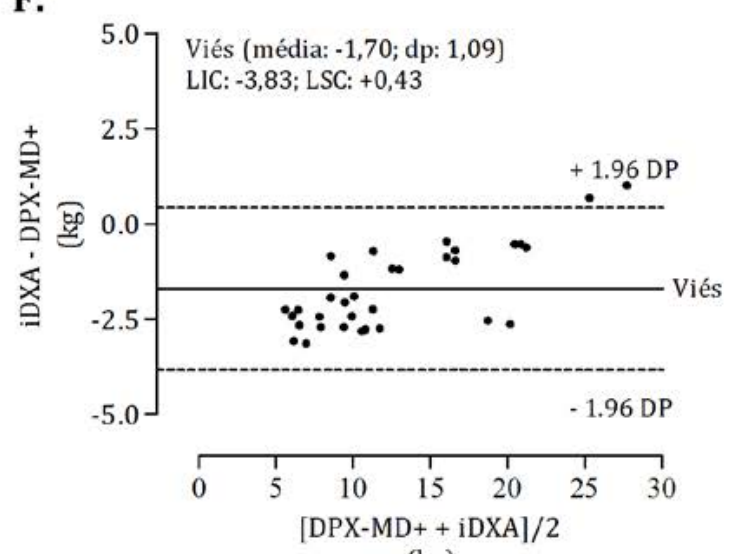

(kg) 
evaluated. Also, in another study with 40 postmenopausal women, accuracy of repeated BMD measurements was 1.1-1.6\% for the lumbar spine and 2.2-2.5\% for the femoral neck, with intraindividual variation being highest for obese women. ${ }^{31}$

For fat tissue, it is possible that variations in energy and data processing associated with each of the equipments contribute to a substantive intraindividual difference and caution is recommended for the acceptance of fat mass data, expressed in $\mathrm{kg}$, from the DXA technology. In the present study, this variable showed the highest value for CV \% (11.2\%) and the magnitudes of intraindividual differences were large. Regarding lean soft tissue, the data between DXA-MD+ and iDXA appeared to be in agreement, except for ROI, where it is considered an additional source of error, that is, the error introduced by the observer, also involving data processing and not just acquisition. Use of DXA for determination of trunk fat, combined with measurements and thickness of subcutaneous fat folds, was tested as a protocol to obtain an intra-abdominal fat quantification using computed tomography ${ }^{14}$ having explained $91 \%$ of the interindividual variance, although with a CV \% of $14.8 \%$.

Appendicular composition has also been of interest in several studies using DXA technology. For example, a study of 41 male rugby players (16.3 to 20.7 years old) calibrated the geometric models by anthropometry to determine the lower limb volumetry, based on data obtained by DXA (Hologic, Explorer W, Waltham, Massachusetts, USA, software QDR version 12.4) to obtain data on fat mass and fat-free mass of the lower limb. ${ }^{21}$ Thus, it was possible to determine correlation coefficients of 0.81 and 0.90 between the anthropometric method and the DXA reference. More recently, the same researchers ${ }^{22}$ has calibrated the geometric models based on two conical structures (only for the thigh) in 168 school-age children using the DXA equipment (Hologic Explor- er W, Waltham, Massachusetts, USA, software QDR version 12.4). In this last study, the appendicular thigh volume corresponded to an ROI defined between the transverse planes that pass between two anthropometric references: ischium and suprapatellar. Finally, another study ${ }^{23}$ has been carried out with 42 adolescent volleyball players (14.0-17.9 years) aiming at anthropometric calibration of thigh volumes obtained by anthropometry and DXA (Lunar DPX NT/Pro/MD+/Duo/Bravo). However, intra-observer reliability for the same equipment has not been determined, particularly with regard to ROI, which requires more expertise from the observer.

\section{CONCLUSIONS}

In general, the various parameters revealed good reproducibility and allowed to confirm a certain idea of the quality of the indicators resulting from the application of competing DXA equipment (Figure 1). Negligible differences were found for BMD, despite a trend for equipment Lunar DPX-MD+ to produce higher numbers for BMC and also for the area. It is recommended, however, that measurements of whole body fat tissue and in the case of lean soft tissue in the thigh, when obtained by DXA, be not taken as a criterion, but rather as a reference. Such an understanding has implications for the interpretation of intraindividual discrepancies that would comprise measurement error in each of the competing variables and not only in the predictive variable.

\section{CONFLICT OF INTEREST}

The authors declare having no conflict of interest. The study was partially funded by the Portuguese Foundation for Science and Technology: uid/ dtp/04213/2016, SFRH/BD/101083/2014, SFRH/ BD/121441/2016, SFRH/BPD/100470/2014.

\section{RESUMO}

OBJETIVO: O presente estudo examinou a concordância entre os indicadores de saúde óssea e composição tecidual resultantes da aplicação de equipamentos concorrentes de absorciometria de raios $X$ de dupla energia (DXA).

MÉTODO: A amostra ( $n=32$ ), com 27,6 $\pm 10,1$ anos de idade avaliados antropometricamente, inclui impedância bioelétrica com multifrequência e pletismografia de ar deslocado. O conteúdo mineral ósseo (CMO), a área de tecido ósseo, o tecido magro e o tecido gordo de corpo inteiro foram obtidos considerando o modo pencil beam (Lunar DPX-MD+) e o fan beam (Lunar iDXA). Para cada um dos equipamentos, foi efetuado um scanner proximal do fêmur, sendo produzida informação sobre a densidade mineral óssea (DMO) do colo, nomeadamente triângulo de Ward, trocanter e haste. Na fase de processamento, foi definida uma região de interesse (ROI; coxa direita). As análises compreenderam a diferença de médias de medidas repetidas com cálculo da magnitude de efeitos (d), coeficiente de correlação intraclasse (CCI), coeficiente de variação (CV). 
RESULTADOS: Foram obtidos CCl>0,900 para todas as medidas, com diferenças intraindividuais largas apenas para CMO ( $d=1,312$; $C V=2,7 \%)$, área de tecido ósseo ( $d=1,761 ; C V=2,7 \%)$, tecido gordo total ( $d=1,612 ; C V=11 \%)$ e tecido magro em todos os segmentos $(d=1,237-1,687 ; C V=2,0-4,1 \%)$. A massa magra da $R O I$ apresentou uma variação intraindividual muito larga $(d=4,014 ; C V=8,4 \%)$.

CONCLUSÃO: Foram encontradas diferenças negligenciáveis para a DMO de corpo todo. As medidas de massa gorda e massa magra obtidas por DXA não devem ser tidas como critério, mas antes como referência, muito especialmente quando se delimita uma ROI.

PALAVRAS-CHAVE: Absorciometria de fóton. Densidade óssea. Composição corporal. Atletas.

\section{REFERENCES}

1. Heymsfield SB, Pietrobelli A, Wang Z, Saris WH. The end of body composition methodology research? Curr Opin Clin Nutr Metab Care. 2008;8(6):591-4

2. Silva AM, Minderico CS, Teixeira PJ, Pietrobelli A, Sardinha LB. Body fat measurement in adolescent athletes: multicompartment molecular model comparison. Eur J Clin Nutr. 2006;60(8):955-64.

3. Wells $\mid C$, Fewtrell MS. Measuring body composition. Arch Dis Child 2006;91(7):612-7.

4. Stewart $A D$, Hannan W|. Prediction of fat and fat-free mass in male athletes using dual $\mathrm{X}$-ray absorptiometry as the reference method. J Sports Sci. 2000;18(4):263-74

5. Lohman TG, Chen Z. Dual energy X-ray-absorptiometry. In: Heymsfield SB, Lohman TG, Wang Z, Going SB, eds. Human body composition. Champaign: Human Kinetics; 2005. p.63-78.

6. Cameron JR, Sorensen J. Measurement of bone mineral in vivo: an improved method. Science. 1963;142(3589):230-2

7. Slaughter MH, Lohman TG, Boileau RA, Horswill CA, Stillman RJ, Van Loan MD, et al. Skinfold equations for estimation of body fatness in children and youth. Hum Biol. 1988;60(5):709-23.

8. Kohrt WM. Body composition by DXA: tried and true? Med Sci Sports Exerc. 1995;27(10):1349-53.

9. Sardinha LB, Lohman TG, Teixeira PJ, Guedes DP, Going SB. Comparison of air displacement plethysmography with dual-energy $X$-ray absorptiometry and 3 fields methods for estimating body composition in middle-aged men. Am J Clin Nutr. 1988;68(4):786-93.

10. Foster BJ, Platt RW, Zemel BS. Development and validation of a predictive equation for lean body mass in children and adolescents. Ann Hum Biol. 2012;39(3):171-82.

11. Ruetsche $A G$, Lippuner $K$, laeger $P$, Casez IP. Differences between dual- $X$ ray absorptiometry using pencil beam and fan beam modes and their determinants in vito and in vitro. | Clin Densitom. 2000;3(2):157-66.

12. Svendsen OL, Harboo J, Hassager C, Christiansen C. Accuracy of measurements of total body soft tissue composition by dual-energy $\mathrm{X}$-ray absorptiometry in vivo. Am J Clin Nutr. 1993;57(5):605-8.

13. Svendsen OL, Harboo I, Hassager C, Christiansen C. Accuracy of measurements of total-body soft-tissue composition by dual energy $\mathrm{X}$-ray absorptiometry in vivo. Basic Life Sci. 1993;60:381-3.

14. Svendsen OL, Hassager C, Bergmann I, Christiansen C. Measurement of abdominal and intra-individual fat in postmenopausal women by dual energy X-ray absorptiometry and anthropometry: comparison with computerized tomography. Int | Obes Relat Metab Disord. 1993;17(1):45-51.

15. Heymsfield SB, Smith R, Aulet M, Bensen B, Lichtman S, Wang J, et al. Appendicular skeletal muscle mass: measurement by dual-photon absorptiometry. Am J Clin Nutr. 1990;52(2):214-8.

16. Modlesky CM, Lewis RD, Yetman KA, Rose B, Rosskopf LB, Snow $\mathrm{TK}$, et al. Comparison of body composition and bone mineral measurements from two DXA instruments in young men. Am | Clin Nutr. 1996;64(5):669-76.
17. Korth WM. Preliminary evidence that DEXA provides an accurate assessment of body composition. . Appl Physiology (1985). 1988;84(1):372-7.

18. Valente-dos-Santos I, Sherar L, Coelho-e-Silva MI, Pereira |R, Vaz V, Cupido-dos-Santos A, et al. Allometric scaling of peak oxygen uptake in male roller hockey players under 17 years old. Appl Physiol Nutr Metab. 2013;38(4):390-5.

19. Carvalho HM, Coelho-e-Silva MI, Figueiredo AJ, Gonçalves CE, Philippaerts RM, Castagna $C$, et al. Predictors of maximal short-term power outputs in basketball players 14-16 years. Eur J Appl Physiol. 2011;111(5):789-96.

20. Carvalho HM, Coelho-e-Silva MJ, Valente-dos-Santos |, Gonçalves RS, Philippaerts R, Malina RM. Scaling lower-limb isokinetic strength for biological maturation and body size in adolescent basketball players. Eur J Appl Physiol. 2012;112(8):2881-9.

21. Carvalho HM, Coelho-e-Silva MJ, Franco S, Figueiredo AJ, Tavares OM, Ferry $B$, et al. Agreement between anthropometric and dual-energy X-ray absorptiometry assessments of lower-limb volumes and composition estimates in youth-club rugby athletes. Appl Physiol Nutr Metab. 2012;37(3):463-71.

22. Coelho-e-Silva MI, Malina RM, Simões F, Valente-dos-Santos I, Martins RA, Vaz Ronque ER, et al. Determination of thigh volume in youth with anthropometry and DXA: agreement between estimates. Eur J Sport Sci. 2013;13(5):527-33.

23. Tavares ÓM, Valente-dos-Santos ], Duarte JP, Póvoas SC, Gobbo LA, Fernandes RA, et al. Concurrent agreement an anthropometric model to predict thigh volume and dual-energy X-Ray absorptiometry assessment in female volleyball players aged 14-18 years. BMC Pediatr. 2016;16(1):190.

24. Jones PR, Pearson J. Anthropometric determination of leg fat and muscle plus bone volumes in young male and female adults. | Physiol. 1969;204(2):63P-66P

25. Harriss DI, Atkinson G. Ethical standards in sport and exercise science research: 2016 update. Int J Sports Med. 2015;36(14):1121-4

26. Lohman T, Roche A, Martorell R. Anthropometric standardization reference manual. Champaign: Human Kinetics; 1988.

27. Hopkins WG, Marshall SW, Batterham AM, Hanin J. Progressive statistics for studies in sports medicine and exercise science. Med Sci Sports Exerc. 2009;41(1):3-13.

28. Tothill P, Hannan W]. Comparisons between hologic QDR 1000 W, QDR 4500A, and lunar expert dual-energy X-ray absorptiometry scanners used for measuring total body bone and soft tissue. Ann N Y Acad Sci. 2000;904:63-71.

29. Genton LD, Hans D, Kyle UG, Pichard C. Dual-energy X-ray absorptiometry and body composition: differences between devices and comparison with reference methods. Nutrition. 2002;18(1):66-70.

30. Griffiths MR, Noakes KA, Pocock NA. Correcting the magnification error of the beam densitometers. | Bone Miner Res. 1997;12(1):119-23.

31. Patel R, Blake GM, Rymer J, Fogelman I. Long-term precision of DXA scanning assessed over seven years in forty postmenopausal women. Osteoporos Int. 2000;11(1):68-75 